\title{
Uremia-induced lysine modifications transform plasma albumin into a high-density lipoprotein receptor inhibitor
}

\author{
Veronika Binder, Michael Holzer, Dalia El-Gamal, Sabine Dirnberger, Gunther Marsche* \\ From 18th Scientific Symposium of the Austrian Pharmacological Society (APHAR). Joint meeting with the \\ Croatian, Serbian and Slovenian Pharmacological Societies. \\ Graz, Austria. 20-21 September 2012
}

\section{Background}

Protein damage induced by retained uremic solutes may be an important component in the pathophysiology of advanced renal disease. Albumin isolated from hemodialysis patients was recently shown to block high-density lipoprotein (HDL) receptor-mediated cholesterol uptake. However, post-translational modifications that render albumin a scavenger receptor class B type I (SR-BI) ligand are not known. We hypothesized that the elimination of positive charge through oxidation of albuminlysine residues is required to generate recognition motifs for SR-BI. Since carbamylation and carboxymethylation are major lysine modifications in vivo, we aimed at investigating their influence on the binding properties of HDalbumin to SR-BI.

\section{Methods}

Albumin from HD patients and control subjects was isolated from serum by affinity chromatography. Mass spectrometry was used to study structurally defined lysine modifications on HD-albumin. Competition experiments (displacement of Alexa-labeled HDL) were performed to assess binding affinity of modified albumin to SR-BI.

\section{Results}

We identified a significant increase in 3-chlorotyrosine, carbamyllysine and carboxymethyllysine content on HDalbumin. Competition experiments revealed that chlorolysine and carbamyllysine mediate binding of AOPP-albumin to SR-BI whereas binding properties of carboxmethyllysine did not differ significantly from native albumin.

\footnotetext{
* Correspondence: gunther.marsche@medunigraz.at

Institute of Experimental and Clinical Pharmacology, Medical University of Graz, 8010 Graz, Austria
}

C 2012 Binder et al; licensee BioMed Central Ltd. This is an Open Access article distributed under the terms of the Creative Commons Attribution License (http://creativecommons.org/licenses/by/2.0), which permits unrestricted use, distribution, and reproduction in any medium, provided the original work is properly cited.
Cite this article as: Binder et al: Uremia-induced lysine modifications transform plasma albumin into a high-density lipoprotein receptor inhibitor. BMC Pharmacology and Toxicology 2012 13(Suppl 1):A40.

Submit your next manuscript to BioMed Central and take full advantage of:

- Convenient online submission

- Thorough peer review

- No space constraints or color figure charges

- Inclusion in PubMed, CAS, Scopus and Google Scholar

- Research which is freely available for redistribution
- Immediate publication on acceptance 